\title{
Retorikkens rum eller byens hundrede tusinde romaner
}

Litterær rumforskning med Genette og Balzac

Søren Pold

quand on le met sur Balzac, c'est comme le stéréoscope.

Marcel Proust

Hvad er et litterært rum? Hvordan ser det ud, og hvordan kan man tale om det? Følgende artikel forsøger at give et forholdsvist konkret svar på disse spørgsmål ved at tage fat $i$ et par klassikere. Først nogle grundlæggende omend lidt oversete overvejelser inden for den litteraturteoretike rumforlening i tre tidlige essays hos den fronse strukturalining it tre tidige essays hos den freske strentist Gerard Genete. Dernast en redegorelse for hvordan gadens tale bliver th roman i Honore de Balzacs Ferragus fra Histoire des Treize - en roman der kan læses som et laboratorium, hvor han udvikler den moderne storbyroman. Den urbane litterære form udvikles her i en tæt sammenhæng med rummet, $\mathrm{Pa}$ ris, som ikke vil finde sig $i$ kun at være baggrund og kulisse for repræsentationen men blander sig $i$ både udsigelse og udsagn på flere niveauer.

Litteratur og rum

I essayet „La littérature et l'espace“ har Genette valgt at fokusere på litteraturens spatiale relationer er $i$ bevidst opposition til de langt behandlede temporale dimensioner, som måske også umiddelbart er mere primære i kraft af narrationens og læsningens temporale, lineære fremadskriden. Andre kunstformer har mere direkte og essentielle relationer til rummet. Maleriet og skulpturen bliver direkte udført i deres eget rum ud over, at de selvfølgelig repræsenterer et rum. Og arkitektur, som er rummets kunst par excellence taler ikke om et rum, ,det ville være mere sandt at sige, at den

PASSAGE 3I/32 - I999 fẩr rummet til at tale, at det er rummet, der taler den, og om den" (Genette 1969, p. 44) - Genette overvejer derefter, hvorvidt det er muligt at finde en analogi til dette rum i litteraturen. Om litteraturen har en aktiv repræsenterende og betydende spatialitet? Et rum som er indeholdt i og del af litteraturen udtryk; kort sagt et specifikt litterært rum?

Det er selvfølgelig let at tale om et denotativt rum i litteraturen. Et rum indeholdt i beskrivelser parallelt med det rum som maleriets perspektiv udpeger. Men greb om et konnotativt rum. Et rum som taler og er betydende snarere end talt om, betydet; et litterær figur-rum..$^{2}$ På jagt efter et sådant rum opregne enette spatiale elementer i sproget og litteraturen. Fra strukturalismens grundloggende antagelse om progsystemalsmens grundlæggende antagelse om kelle til Bor sot netværk udspændt af rene forverselt bilitive forestilling om et uniBlotek. Et verdensomspændende bibliote hvor tekster kor danner et stort, simultant domæne, nyt lys på hinanden på tværs af litteraturhistorien og på tværs af det enkelte værk og dets temporale linearitet. En forestilling der nok hos Borges (fx i Bi-

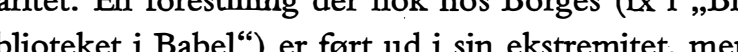
(licter, me som a in las som fo ninger samt potentielt xndrer og reaktualiserer disse. Imellem disse ekstremer - mellem det lingvistiske laboratorium og det intertekstuelle verdensbibliotek - nævner Genette forhold som skiftens materialitet (som den bliver udforsket fra Mallarmé og Apollinaire). Han kommer også ind på læsningen ikke-lineære spatialiseringer, dvs. de relationer, kon- 
vergenser og tilbagevirkninger som etablerer sig mellem episoder, som er meget langt fra hinanden den lineære læseakts tidslige kontinuum. I den forstand stiller hản det meget aktuelle spørgsmål (hypertext-teorierne taget $\mathrm{i}$ betragtning), om det overhovedet giver mening at betragte bogen og romane som et live som et linear, tidigt loninuert medium, hvis man ikke bot betager det fysiskemedin, ger leseprocessens betydningsproduktion med i sin overvejelse

At lase som man bør lase sådanne værker (er der andre måder?) er at genlese, altid allerede at genlese, ustandselig at lobe igennem en bog $i$ alle retninger, $i$ alle dimensioner. Man kan saledes sige, at hverken bogens eller den enkelte sides rum passivt er underlagt den fortlobende lessnings tid, men i den udstrakning, at tiden viser sig og fuldt udfoldes $i$ lasningen, ophører bogens og sidens rum ikke med at bøje eller omvende tiden og således på en måde ophrve den.

(Genette 1969, p. 46 - oversat andetsteds i dette tidsskrift).

I forbindelse med denne 'læsningens spatialisering' citerer Genette Prousts sammenligning af sit værk med en katedrals rum. Et andet oplagt eksempel (som Genette dog ikke omtaler) på denne ikke-lineære spatialisering af den lineære tekst gennem læsningen er Balzacs værk, La Comédie humaine, hvor personernes og temaernes genkomst fylder et fiktiv Paris ud, samtidig med at Paris' topografi og punkter $i$ den bliver betydningsbærende, virker som steder man genkender, og dermed forbinder topografien forskellige punkteri interrnt $i$ den enkelte roman og mellem forskellige romaner. Efterhånden som man læser sig ind i værket, vil man gradvist opdage disse forbindelser mellem de forskellige romaner hvorved værkets system vil folde sig ud og sette de hvorved værkets system vil folde sig ud og sætte de enkel plicitte henvisninger til forsynet romaner med eks plicite he Biscinger til andre romaner. Jeg vender tilbage til Balzac men vil
ved Genette.

\section{Retorik og rum}

I essayet „Figures“ etablerer Genette et figur-begreb fra den klassiske retoriks elocutio, som kan betragtes som forfader til moderne semantik og stilistik. Han citerer (fra Fontanier) den almindelige antagelse, figuren arbejder i - og er den form som bliver aftegnet af afvigelsen [,écart"] mellem bogstav og betydning, mellem det forfatteren har skrevet og det, ha har tenkt. Denne afvigelse er et rum, som denner en form, og denne form lanner enter $c$ ins figurer som "de trak, former eller andigheder [tours] ... me hvilken diskursen ... distancerer sig mere eller mindre fra det, som ville have været dens simple og almindelige udtryk" (Figures I, p. 207). Lidt senere skriver Genette parallelt om bevidstheden om den potentielle lakune [,hiatus"] mellem det reelle, poetiske sprog og det virtuelle, ordinære og simple sprog. 3

I modsætning til tidligere retorikere fokuserer Genette på de spatiale aspekter af denne indre afstand i sproget. Ideen om et internt rum, en lakune, i sproget ser han som selve retorikkens esprit og som litteraturens form eller synlige korpus". litteratens forn rum ille ton særlig forn for elokvens eller poesi. Fof aterens kun hænger sammen med den måde, hvorpå han afteg-

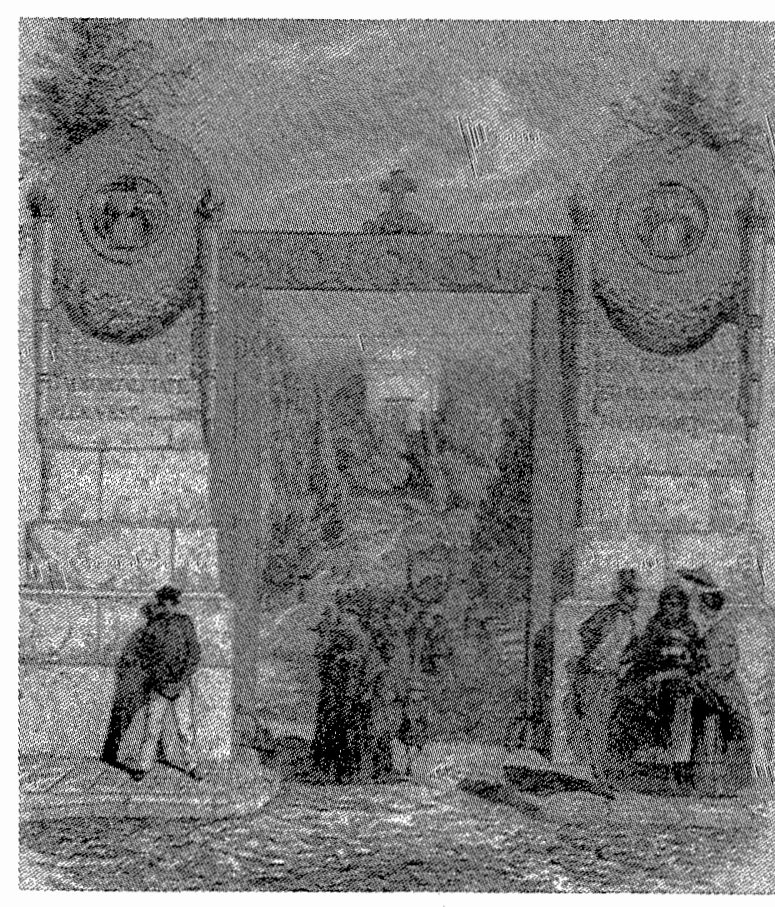

Indgangen til Père-Lachaise (1888). ner dette rums grænser, hvilket er litteraturens synlige korpus." (Genette 1966, pp. 207-208). Det figurative sprog, litteraturen, får på denne måde et eget, internt, formelt rum, afgrænset af hvordan forfatteren bearbejder sprogets lakuner og afvigelser og dermed genererer en litterær form og betydning.

Desu Desuden papeger Genette en udbredt affinitet mellem sprogets kategorier og kategorier der har med udstrakthed at gøre, hvilket resulterer i, at man bruger spatiale metaforer til alle mulige formål. At tale om spatiale metaforer bliver i sig selv næsten til en pleonasme, og selv termen figur implicerer et plastisk rum. På denne måde henleder Genette opmærksomheden på et rum, som er en del af sprogets og litteraturens form ved siden af det rum, som er en del af indholdet.4

På vej mod en spatial analyse?

Litteraturteori har beskæftiget sig indgående med temporale aspekter $-\mathrm{jkke}$ mindst de godt 30 år, der er gået siden Genettes essays. Hvilke konsekvenser har det at vende opmærrksomheden mod spatiale aspekter i litteraturen? Genettes motivation og hopekter i litteraturen? Genettes motivation og ho-
vedeksempel er Proust og hans kamp mod SainteBeuves diakroniske perspektivs 'tyranni', og Genette foreslår at se Prousts værk som en spatialisering af tiden i modsætning til den fremhérskende temporalisering af rummet.

Det litterære værk og dets vokabular eller form bliver en spatial konstruktion, som ikke kun, mere eller mindre realistisk, repræsenterer et eksternt rum uden for teksten, men som selv er en aktiv form der informerer eller transformerer sit objekt(rum): en epoles (eller et varks) vokabular er ikke len”... objekter ellerider, men en amling af objekr ellerider, men en alfiv forn, som udstanser det reelle pá sin sanlige made... (Genette, 1966, p. 108) - Rummet blive både talt om og taler selv i moderne litteratur, det fungerer både $i$ udsigelsen og i det udsagte. Genette konkluderer i „Espace et langage", at relationen mellem sprog og rum er tovejs $i$ en chiastisk forbindelse, ,hvor sproget [, langage"] rumliggør sig samtidig med at rummet, når det er blevet sprog taler sig og skriver sig. 5
Som det fremgår er det en kompleks problematik, som $i$ sidste ende kun kan illustreres og forstås i sammenhæng med litterære værker og analysen af dem. Men det er muligt at ane konsekvenserne for $\mathrm{fx}$ studiet af moderne bylitteratur. Analysen vil soledes live nodt til hade at have oje for de frem saledes ence orpå det litterære værk transformerer og informerer denne by. På denne måde kan en sådan læsning nå frem til at konstruere en litterær by i sammenhæng med specifakke værker eller forfattere, Ex Balzacs Paris. Samtidig udgør strategien en bestræbelse på at undgà både formalistiske og historistiske grøfter; at undga at litteraturen lukker sig hermetisk om sig selv eller reduceres til udsagn om historisk virkelighed eller diskurs. Bylitteratur kan således ikke reduceres til at være udsagn om en given (historisk) by, og det e ikke min hensigt med dette at ende $i$ udsagn à la man kan ikke lase Balzac uden at have vert 'man kan lo lase Balac unen at have veret realistisk litteratur - at undersøge forbindelser pà forskellige planer mellem kontekstens rum og tekstens rum. At undersøge hvordan litteraturen bearbejder og producerer en kontekst - kort sagt hvad litteraturen ved om virkeligheden og virkeligheden egne fremstillingsmekanismer. Eller med Christopher Prendergast, som i sin bog om Paris i det nittende århundredes litteratur netop bestræber sig $\mathrm{p}$ at holde dette dobbeltblik mellem tekst og kontekst åbent: „En måde at sige det på er, at 'historien' ikke er bag teksten, men i teksten, i dens sener, teksturer, syntaks, vokabular, som en artikulationsproces; g selvom dette skift af preposition rejer mange ol spen potivis at være stiv engagement med sprog og litteratur som i sig selv aktive forme" (Prendergast, p. 22). ${ }^{6}$

Genette hævder som yderste konsekvens at denne chiastiske dialektik mellem rummet i det udsagte og udsigelsen er essentiel i forhold til, hvordan retorikken og dens figurer arbejder. I en kort pointerende sætning (fra „Figures“) samler han sine pointer op som de ser ud fra retorikkens synsvinkel og siger 
„Figuren er en afvigelse $i$ forhold til brugen, men denne afvigelse er imidlertid i brug: Dette er selve retorikkens paradoks."7

Romanbyen - gadens tale

Paris er scenen i mere end halvdelen af $\mathrm{La}$ Comëdie humaines knap roo romaner, og Balzacs personer gennemtraver byen $i$ deres forsøg på at forstå o beherske den. Samtidig bliver hans værk en uadskillelig del af - og forudsætning for - det nittende århundredes Paris. Christopher Prendergast fremhæver, hvordan La Comédie humaine bliver en slag arke-tekst for de senere Paris-værker, som de enten forsøger at genskabe eller unddrage sig og fremhæve som en fiktion i deres fiktion (Prendergast 1992, p. 29). Men Paris er mere end scenografi for Balzac, som faktisk gør byen til både protagonist, modellæser og forfatter.

I Histoire des Treize (1833-35), som består af tre består af tre hver godt roo sider lange romaner, eksperimentere Balzac for forste gang med at bruge genkommend personer som forbindelsesled mellem de tre små romaner, en teknik der, som jeg har været inde $\mathrm{p}$ rumliggør læsningens tidslige linearitet og peger $\mathrm{p}$ det rum, hvor personerne bor og handler. På samm tid arbejder han med brugen af det parisiske, urban rum, som spiller en stor rolle for de tre romane ikke mindst Ferragus, hvor der ud over de lange indledende beskrivelser af - og overvejelser over - by rummet arbejdes med byrummet $i$ både fortællingens plot og dens konklusion.

Ferragus er en form for prototypisk kriminalhistorie men uden nocet forudgånende mord. Alle dodsfaldene folcer af de forkellige deteltiveners opklaringsforog og ensidige fors hiring hiandens opklaring af - og kontrol med plottet. Som $i$ ethvert godt (Clemence) Jules, hen af modgang, mens den unge og noget tvetydige helt (Auguste de Malincour) dør som følge af et giftmord. Skurken, galejslaven Ferragus, som er far til Mme Jules, slipper levende fra historien og er bitter på grænsen til det psykotiske resten af sine dage, mens ægtemanden, Jules Desmaret, fatter sammenhængene for sent og medvirker kraftigt til at forkludre alt. Dertil kommer adskillige bipersoner, der bliver hvirvlet ind $\mathrm{i}$ plottet, som $\mathrm{fx}$ den unge i Ferragus forelskede pige, Ida Gruget, der tager sit liv ved at springe i Seinen. Disse karakterer, og flere til, interagerer på romanens godt hundrede sider med en kompleksitet, elv kan redegøre for

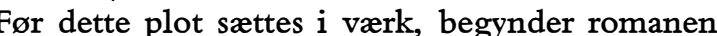
med nogle overvejelser over byen, og hvordan byen er påvirket af og samtidig påvirker dens indbyggere: „Kort sagt, Paris' gader har nogle menneskelige egenskaber, deres fysiognomi indprinter os visse ideer mod hvilke vi er forsvarsløse." (Balzac, p. 793). Byboeren urbaniseres, samtidig med at rummet antropomorfiseres. Gader og huse sammenlignes med kroppe eller monstre med hoveder, maver og fødder. ${ }^{8}$.

Fortællerinstansen (som lnapt kan holdes sammen $i$ en) urbaniseres samtidig. Hvad der umiddelbart ligner en suveren iagttagers klare blk viser sig marere at tilhore en type, som bestemt itke kan sig a ester undskylder denne "debut vagabond", der eksplici liver forbundet med flanørens mobile optik. En optik der ovenikøbet også udbredes til at dække romanens ideallæser:

Disse observationer, som er uforstålige uden for Paris, vil uden tvivl blive opfattet af de mænd af tanke og studie, af poesi og nydelse, som, mens de flanerer gennem Paris, forstår at indhoste massen af Alygtige fornojelser mellem byens mure døgnet rundt.

Saledes bliver byrummet indskrevet såvel som beskrevet i fortællingen. Både fortælleren og ideallæ-

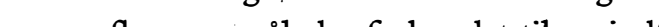
by sorbundet til og indfolde i byen og dens the ingen gennemfrres kort sagt på băde indholds- og udsigelsesplan og influerer bàde fortæller og modelweser, eller det forventes med andre ord, at man læser romanen, som fortælleren læser byen.

Set fra byens side beskriver fortællingen, hvordan byens rum gennem byens dynamik bliver både ubegribelig ustabilt og betydende i sig selv. Rumme undviger en stabil beskrivelse og pladsen som beteg- net til fordel for selv at blive betegnende. Som der direkte står: „Artikulationerne knager umærkeligt, bevægelsen kommunikeres, gaden taler." [,Insensiblement les articulations craquent, le mouvement se communique, la rue parle."] (Balzac, p. 794).

Det er denne byens dynamik, kommunikation og Deter de, la byens dy tale, som Balac borklare eller fortlle dene "mouvante reine des cités"; for at erfare dens fortælling, erkende dens dynamiske plotmaskineri, hvordan den „indprinter os visse ideer, mod hvilke vi er forsvarsløse". Byen bliver for den flanerende fortæller til forfatteren ,byen med de hundrede tusinde romaner", hvis utallige værker kun skal opdages og skrives ned:

...Paris er altid dette monstrose mirakel, en forunderlig samling af bevagelser, af maskiner, af tanker, byen med de hundrede tusinde romaner, verdens hoved. (Balzac, p. 79).

På denne måde influerer den moderne by, dens bevægelser og hastighed kraftigt på læsningen eller æà modellæseren, som altsà er en flanør (eller som via fortællernes flaneren bliver det qua romanens omstrejfen). Samtidig er byen $i$ en vis forstand både forfatter og protagonist. - Dette motiv oin det moderne, bevægelige samfund, som kun har brug for en sekretær for at blive til romaner gentages i øvrigt flere gange af Balzac, bl.a. eksplicit i hans forord til La Comédie humaine. Ofte begynder Balzacs romaner $i$ et kvarter, en gade i Paris, søgende efter et plot, som langsomt åbenbares - som om Balzac blot har ladet sin fortæller falde ned i en parisisk topograf for at se, hvilke fortællinger denne topografi måtte generere.

I Ferragus foregår det specielt tydeligt. Plottet vokser direkte ud af det urbane rum, den parisiske topografi, og det udvikler sig gennem det forhold, at protagonisterne (og med dem ogsa fortællerpositionerne) er indesluttet af det og ikke er $i$ stand til at overskue det fuldstændigt. Det bliver tydeligt demonstreret allerede fra det sted, hvor plottet sættes igang efter de indledende beskrivelser af og refleksioner over Paris:
Klokken halvni om aftenen i rue Pagevin, på en tid hvor rue Pagevin ikke havde en mur, som ikke repeterede et infamt ord og i retning mod rue Soly den mest smalle og mindst femkommelige af alle Paris' ader, uden at undtage det wenkventerede hjome i den mest tomme gade, i begrndet de trede en ung mand, ved et af disse tifalde som ikke hænde to gange i livet, til fods om hjømet af rue Pagevin for at ga in $i$ rue des Vieux-Augustins, på hojre hånd, hvor rue Soly precist befandt sig. Der fandt denne unge mand, som boede i rue de Bourbon, i den kvinde, som han gik aldeles sorgløs nogle skridt fra, nogle svage ligheder med den smukkeste kvinde Paris, en kysk og yndig kvinde som han var hemmeligt forelsket i, og forelsket uden håb: hun var gift. I et đjeblik bankede hans hjerte, en ulidelig varme valdede frem af hans mellemgulv og passerede i alle hans årer, det lob ham koldt ned af ryggen, og han folte en overfladisk skælven. Han elskede, han var ung, han kendte Paris; og hans skarnsyn tillod ham ikke at is norere att huad der kune lige of mulig hkendel i for norere alt, hud der hane ligge af mulig skendsel i for $e$ phinde, som var elegant, ing, ung og snuk at ga omkring der ette smuds, på dette

Man kan her konkret iagttage, hvordan plottet vokser frem af den parisiske topografi; hvordan byen bevægelse og gadens tale opfattes af den opmærksomme flanør-fortæller, som tilfældigt krydser denne hændelse eller instans af sammenvævet tid os sted. Handlingen starter med at flanøren, Auguste de Malincour tilfældigt ser Mme Jules $i$ et område af Paris, hvor hun ikke burde være på dette tidspunkt. I det lange afsnit bvor syntaksen er ligeso labyrintet lange afsic hasing labyrintisk som de parisiske gader $i$ det skumle kvarter bag Les Halles og Palis Royal, femlagges, hvordan rofor forkerte sted på det forkerte tidspunkt i forhold til, hvor hun hører hjenme. Hun ses oven i købet a den forkerte person, hvilket relateres til, hvor han stammer fra i byen. Samtidig stedsbestemmes handlingen i forhold til resten af Paris og den tidsbestemmes $i$ forhold til det tidspunkt, romanen er skrevet. Alt er således vævet ind $i$ hinanden, både syntaktisk topografisk og temporalt, og plottet, som resten a romanen drejer sig om, udtrykkes koncentreret 
den sætning, der afslutter passagen og artikulerer dens sammenvævining af tider og steder: „Hende, dette smuds, på dette tidspunkt!" ‘xo Som flanørens vandren rundt uden et fast mål søgende tilfæaldigt efter hvadsomhelst, der måtte være specielt og rumme betydning, driver både sætningerne og romanen rundt og samler betydningsfulde fragmenter i det sammenvævede urbane rum, indtil den er rede til at fremsætte en sætning, der samler op på hændelsen og binder det hele sammen $i$ et plot.

Dette komplekse Paris fyldt med tilfældige hændelser dominerer hele romanen, og plottet udvikler sig, som nævnt, omkring de forskellige personers forsøg pà at udrede og kontrollere kompleksiteten og beherske plottet. Ferragus er fyldt med detektiver, som prover på at afdække og beherske plottet, for eksempel ægtemanden, Jules Desmaret, den unge helt, Auguste de Malincour, Ferragus og dertil kommer diverse hjælpere og tjenere. Men ved deres handlinger lykkes det dem ikke at overskue eller ennemskue plottet men derimod kun at foje nye elemer til og derved gare det endnu mindre nye en nemsigtigt og kentrollabelt. For eksenpel forărsage Alere af hovedpersonerne pa forskellige måder en kommunikation af halve sandheder med forkerte forudsætninger og begrænsede synsvinkler med utallige blinde vinkler. Enten som et bevidst forsøg på at holde noget skjult for andre eller ufrivilligt ved at de bliver udspioneret af spioner med begrænset udsyn og viden.

De enkelte personers begrænsede horisont eller overblik danner således romanens hovedmønster og genererer plottets dynamik. Plottet spiller konstant med det begrænsede udsyn som en device, der genererer plottets gader: fra det ukendte oo anonyme vidne til de tre historier der udror samlinon vire des Trize til det posingen Hisvire des The tis detes, hor her nødvendig diskretion (Balzac, p. 883). Denne diskretion er historiens primære hemmelighed; at hun er datter af den kriminelle galejslave, Ferragus, og således forbinder de laveste sociale klasser og fattige kvarterer omkring Les Halles (hvor han bor - de var derfor hun var der) med det nye financielle borgerskab omkring Chausée d'Antin — hvormed hun udgør det fordækte link, der lader pengene cirk lere.

Pa denne måde bevæger fortællingen sig igennem Paris' komplekse rum og støder på den ene tilfærdige hændelse efter den anden indtil Mme Jules uttimative dod. Hun er, som bekendt den karater plotet drejer sig om som indehaver af den priner permelighed Det milykes ulimatit for alle ro Det mislykes ulimativt for alle roplot o der de forskellige tråde, des mere bliver mere de følger prisise netrad des mere bliver de fanget $i$ det parisiske netværk. I deres forsøg på at beherske plottet mislykkes det for dem alle at omfatte og tage højde for Paris' meget større netværk af sammenvævet topografi og forbindelser, som byen iscenesætter, som demonstreret i den lange citerede sekvens, hvor plottet initieres.

Det tilsyneladende overblik undergraves konstant af noget bagvedliggende eller underliggende, der demor demonstron orspektiviske begræn ning, som udgaentingent iagttager, de idet parisiske neterk konstrueret som et mix mellem en anonym ekster fortæller, der som typisk hos Balzac kommentere historien og personerne fra sidelinjen uden dog for alvor at demonstrere et holdbart suverænt vidensn veau (hvilket selvsagt også ville ødelægge plottet), og et helt system af interne medsyn med de forskellige hovedpersoner $i$ historien; medsyn der $i$ hoj grad adopterer personernes blinde vinkler og skyklapper og på den måde giver rum for overraskelser og mysterier.

Et godt eksempel er de forskellige breve i romanen, som når de kapres og læses af forkerte modtagere fører til misforståelser, der drejer det skæbnesvangre plot endnu en omgang. For eksempel taber Ferragus et brev skrevet til ham af sin ulykkelige fattige tilbeder, Ida, da han under et regnskyl står i en port sammen med de Malincour. Brevet opsnappes og læses af Malincour, der læser det, som om det kom fra en forsmået elsker, hvilket afsenderen ogsa *or hun er, selvom hendes indbildte rival i virkelig heden er datter til Ferragus. Det kommenteres me følgende: „De skinsyge tilbedere forestiller sig alt og det er ved at forestille sig alt og vælge de mest sandsynlige udfald at dommere, spioner, elskere og iagttagere gætter den sandhed, som interesserer dem" (Balzac, p. 8I8). Umiddelbart kunne det lyde som en kommentar fra fortelleren om, hvordan de Malincours jalousi leder ham i den rigtige retning. Malincours jloui la for hat $i$ den rigtige retning. Men efter at have rere konket fulde drivkraft $i$ opbygningen af det system af misforstålser, som driver det skæbnesvangre plot. Hvis man genlæser citatet med denne viden, kan man iagttage, hvordan fortælleren har helgarderet ved sætningens slutning (,gætter den sandhed, som interesserer dem" / "devinent la vérité qui les intéresse."), og sætningen kan nu forstås som kritisk mod interessebetonet udforskning hos dommere, spioner, elskere og iagttagere. Senere lykkes det Jules Desmaret at få fat $i$ et brev fra Ferragus til sin datter Mme Jules. Brevet er kodet men det lykkes Jules Desmaret at bryde koden via sin ven, embedsJules Desme Jues. mermed kan de lase berer hig med almind hig fad katter, Mme Jules, hvilket af den jaloux ægtemand, Jules, læses som kærlighedserklæringer fra en elsker. Med andre ord lykkes det dem at bryde den tekniske kode, men de fejlfortolker til gengæld den semantiske kodning af brevet, der bestemmes af, at det er et brev fra en fader til sin datter. Det sidste brev, der optræder i romanen, er brevet fra Mme Jules til sin mand, hvor hun efter sin død forklarer sagernes rette sammenhæng - noget som hun ikke kunne fortælle ham, mens hun var $i$ live.

Alle disse breve fungerer tydeligt og næsten demonstrativt i romen som telster, der er loseret montes in fra deres i riddelbre best. Romanen demons tekstmediet fungerer og ændrer betydning, alt efter hvilken kontekst det indgàr 1 , at breve nok er meddelelser mellem mennesker men ogsa er tekster, der kan læses af andre uvedkomne, hvilket har oplagte konsekvenser for læsningen. Romanens plot er som understreget flere gange bygget op omkring og drevet af forskellige detektivers læsninger - og $\mathrm{i}$ hoj grad mis-læsninger - af hinandens handlinger. Ingen af protagonisterne går fri af denne dynamik, hvilket tyder på, at det ikke så meget er spørgsmålet om kloge over for mindre kloge - eller gode over for onde - men at der tværtimod er tale om et vilkår for erkendelse i den moderne storby, hvilket protagonisterne ikke er bevidste om. Den urbane kontekst nitid mulighe 作 protagone selv bevidst eller ubevidst del denne plotproces, som man i mangel af bedre mà betegne som kybernetisk avant la lettre: selvorganiserende udfra forskellige konfliktskabende kræfter samt reguleret af feedback sløjfer. På alle niveauer plottet, samt $\mathrm{i}$ forholdet mellem fortælleren og læseren, spilles der med kontingente medsyn, sekundære indsigter, der skaber et plot drevet af fejllæsningernes og de begrænsede perspektivers dynamik. ${ }^{12}$ Som fortælleren tidligt $i$ romanen bemærker som kommentar til de Malincours næse for de forkellige begivenheder og byens rumlige the og sociale en roman; eller bere, som at spille et drama, oo i dette drama havd han sin rolle" (Balzac, p. 8r2).

Romanen præsenterer kort sagt sit rum gennem et udvalg af indesluttede og forskudte, bevægelige perspektiver, der spejler hinanden som i et spejlkabinet eller som i Mme Jules boudoir, hvor der er ", spejle hvori formerne spilles og som i det uendelige gentager den kvinde som man ønsker at se overalt De forskellige personer forfores allesammen af spejlkabinettets spejlinger. Drevet af deres jaloux begæe fejlfortolker de de forskellige indblik, de får - de er ikke bevidste om - og tager ikke konsekvenser af deres begransede, forkortede og medierede perspektiver men lader sig forfore til at se det, de tros, der for mor lader Ter falde, som laseren typisk ogsa fescopis spejkabinet bestâende af bevægelige perspektiver er det muligt for Balzac at omfatte og fremstille de moderne bys kompleksitet og byrummets heterogenitet, en kompleksitet der udelukker muligheden a at kontrollere eller overvåge byen fra et enkelt centralt perspektiv. Ovenikøbet formår Balzac at fremstille, hvordan den fortsatte 'blinde' tro på de be- 
grænsede og medierede perspektiver $\mathrm{i}$ høj grad er med til at skabe den uigennemsigtige kompleksite Jo mere de stakkels forvildede protagonister ser med dette medierede vision sans regard uden at have udviklet en bevidsthed omkring det - des mindre gennemskuer de. Denne djæevelske logik bliver fremstilet klart og gennemskueligt af romanen, dens kalejdoskopiske spejkabinet og kybemetiske plot.

\section{Det panoramiske blik}

Efter Mme Jules' død og begravelse slutter romanen imidlertid ikke umiddelbart, men fortsætter med tre forskellige konklusioner, som tegner en trekkant uden om det tidlige nittende århundredes Paris. P denne måde får romanen mulighed for at se dens indesluttede, heterogene og uigennemskueligt dynamiske rum på afstand, fra tre punkter, tre kirkegårde der annoncerer den fremtidige by og dens forstadsagtige transit-rum; et neutralt rum uden genre, hvor Paris både er ophørt og stadig er til stede (Balzac, p. 9or). Her slutter romanen og Balzacs Paris løber ud $i$ sandet og bliver decideret sammenlignet med byens modsæetning, ørkenen.

Fra en af disse kirkegårde, Père Lachaise (âbnet r804), fir vi en detajer be, Pese Lachase (abnet 1804), tar vi en detajeret beskrivelse af kirkegården og dens udsigt over Paris. Mme Jules' mand, Jule Desmaret, er taget derop for at se sin kones gray sammen med en ven, men først er han nødt til at

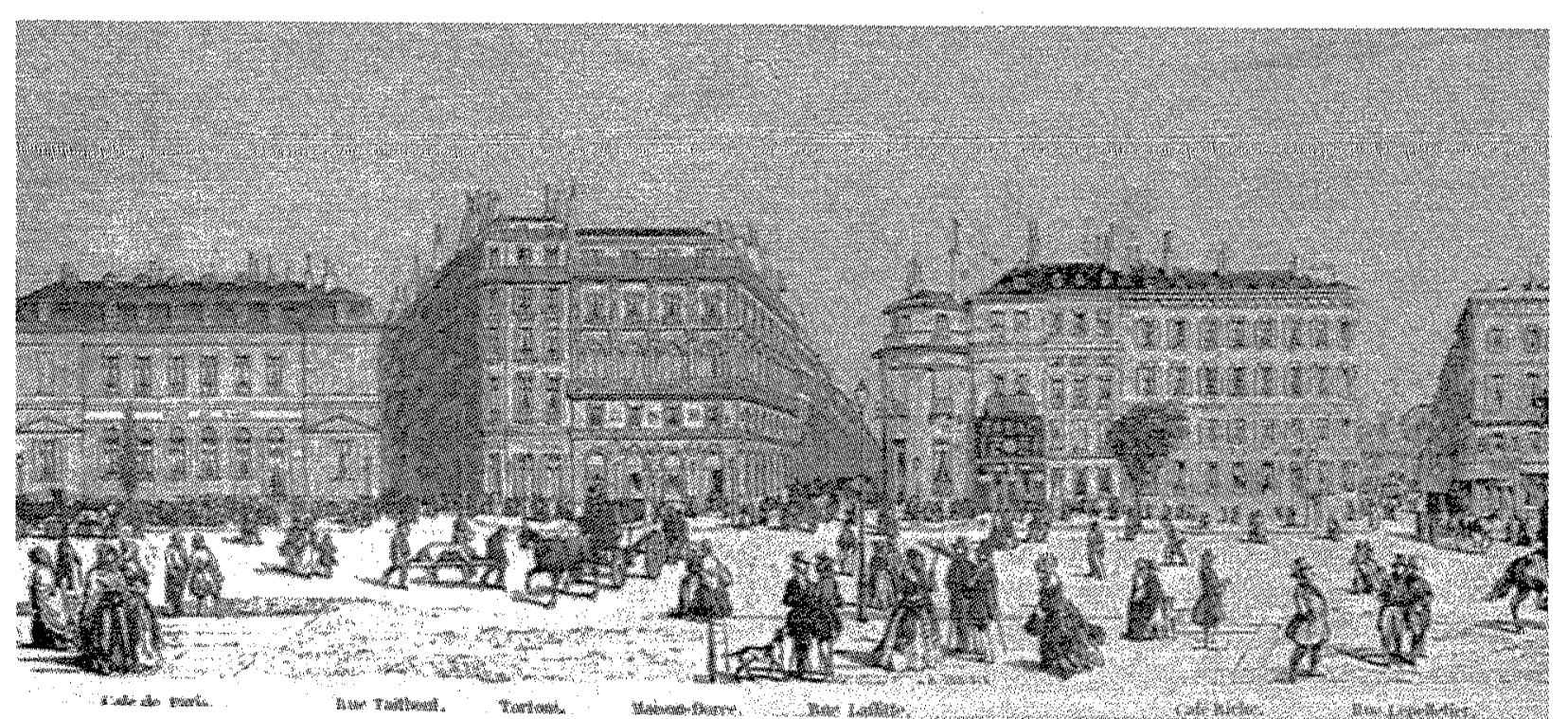

verdens ødelæggende nysgerrighed, som har travlt og trenges mellem hinanden blot for at trenges og have travlt. (Balzac, p. 898)

Byen ses her som et fantasmagorisk, panoramisk stemningsbillede og som lukket om sig selv. Sollysets spillen $i$ byens røg tegner et luftperspektiv på sets spillen $\mathrm{i}$ byens røg tegner et luftperspektiv pà
byen, som ligger indesluttet mellem skrænterne. byen, som ligger indesluttet mellem skrænterne.
Røgeffekten og luftperspektivet giver rummet atmosfære og gør det stofligt og samtidig uklart, uigennemskueligt. På én gang forførende og samtidig illusorisk som et drømmebillede. Jules „omfavnede med et stjålent ojekast" byens fyrre tusinde huse og peger på „rummet indbefattet" mellem Vendôme pladsen og Invalide kirken, mens han resignerer over for den moderne by, som har taget hans kone fra ham. En resignation som til overhånd er udformet som en chiasme, der således stillistisk illustrerer Jules' distance og midakolske magtesloshed over for den moderne, dynamiske by

Dér slutter romanen med en ny tids panoramiske overblik, som består af en død repræsentation, kirkegården, med den virkelige, levende by som baggrund. En dobbelthed i panoramabilledet af repræsentation af byrummet og simulation af et nyt rum, et medierum, hvorved det urbane rum og det urbane blik transformeres til nye former. Et fantasmagorisk overblik, der præsenterer byen som en fetich, der ikke kan nås, gribes eller begribes men sanses distanceret resignerende og melankolsk eller som en "Alygtig fornøjelse" af en flanerende ,âme multiple“" (Balzac, p. 8r3).

Hvordan det kan lade sig gøre at handle og dannes ud fra et salu tovilik nes bage til i en af sine naste store romaner, Le père Goriot. Her viljeg nyemed at rade panoramabiledet stå som et billede på, hvordan byen og romanen virker sammen. Hvordan byens rum indvirker på romanens retorik; både inden for dispositio (eller komposition - $\mathrm{fx}$ : fortallere), inventio (hvordan plottet vokser 'kybernetisk' frem af byen) og elocutio (hvordan byrummet påvirker romanens stilistik syntaks, figurer). Gaden taler.
Samtidig bliver byen litterariseret. Fortællingen bliver en form for praktisering af rummet, en bevægelse i det, en måde at tilfaje det mening gøre det heterogent, beboeligt..14 Som Balzac-teoretikeen Henri Mitterand precist beskriver det: , Romanen, iser siden Balnc, nativeror rummet i ordets pracise beydning. Den gor rummet til en essentiel komponent i den narrative maskine" (Mitterand, p. 17). Den moderne storbyroman, eller i de mindste Pariser-roman, opstår som en genre, som senere Pariser-romaner skal skrive sig ind i og ud af. Paris forvandles $i$ denne proces til „Paris“.

At Pariser-romanernes „Paris“ og det virkelige nittende århundredes Paris er afhængige af hinanden og gensidig transformerer hinanden skulle denne læsning gerne være et konkret eksempel på. I hver fald skulle det gerne være påvist, at det nittende århundredes Paris sætter sig aforrende spor i o decideret former Ferragus' form. Franco Moretti dar for ling iagttages bredlige rum ikke blot er forskellige landskaber men er forskellige narrative matricer. "Ethvert rum determinerer dets særegne former for handling, dets plot dets genre." (Moretti, p. 84). Typisk har forfatter reduceret de sociale rums kompleksitet for at kunn gøre dem læselige $i$ en litterær. form, men Moret fremhæver Balzac som et afgørende brud med denne reduktion. I stedet for at beskytte romane mod Paris' kompleksitet benytter han kompleksiteten til at udfordre formen og skabe en ny kompleksitet i romanformen (Moretti, p. Io6). Moretti argumenterer dermed og gennem sin gennemgang af menterer dermed og gennem sin gennemgang af en oo-tals Pariser- og Londonromaner for at se en sammenhæng mellem rum og

Om Morettis noget hurtige, omend inspirerende, argumentation holder vand og kan bruges $i$ videre udstrækning i litteraturteoretisk forskning må stå hen i det uvisse. Under alle omstændigheder håber jeg med denne artikel at have opnået to ting. For det første med Genette at have peget på en række passager mellem litteratur og rum, selvom det er vanskeligt at tale om et specifikt litterært rum i en streng forstand. Tekst er naturligvis ikke rumlig, lit- 
teratur ikke arkitektur og man kan ikke bo $i$ en tekst, ligesom man ikke kan bo i et bykort eller i cyberspace. Men det er måske litteraturens særegne potentiale i forhold til en rum-diskurs, som tilsynepotence i i for stadig starre rolle estetisk og kultoladende spiller stadig stre rolle astetisk og kultu-

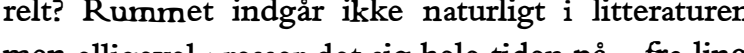
men alligevel presser det sig hele tiden på - fra lingvistikkens laboris bibliotekets intertstualtet kan man hele veje spore en rumlig stræben $i$ en delvist abstrakt (f sprogsystemets rumlighed), delvist konkret proces (fx her Balzacs Paris). Denne rumliggørelse er $\mathrm{p}$ den ene side en proces, hvor romanen bevæger sig ud over linien, dens flade tekstlige udgangspunkt på den anden side er rumliggørelsen en integrere del af ethvert sprogligt, litterært udtryk, som fremstillet af Genette. Når så rummet ikke blot er rent rum men linier, veje, retninger, forbindelser og overlejret af sociale koder som hos Balzac, opstå der en særegen realistisk spejling mellem dette kodede pariske mom dor hele tiden er i ferd med a derive lange citat bvor plottet initieres i Ferragus), og tek stens rumliggorende strategier. Rummets bliven tekst spejler tekstens bliven rum - en realisme de ikke nødvendigvis har noget at gøre med, at teksten stil skal være transparent, men snarere at teksten fremstillingsformer har en affinitet med konteksten fremstillingsformer og medieringer; hos Balzac bliver panoramaet mit nøgleeksempel på dette.

For det andet håber jeg at have demonstreret, a en rumlig tilgang til litteratur ikke nødvendigvis afsnører fortolkningsmulighederne i en gold stedsbestemmelse (lige så lidt som en tidslig tilgang nodvendigvis ender $i$ en gold historistisk tidsbestemmelse). Romaner forteller storartet om rum bestemandet . Rod som i Ferragus at fortle om, buan remet fortler.

\section{Litteratur}

David F. Bell: Circumstances - Chance in the Literary Text

University of Nebraska Press, r993 Gallimard, 1990

Gérard Genette: Figures I, Éditions du Seuil, 1966
Gérard Genette: Figures II, Éditions du Seuil, 1969

Svend Erik Larsen: „Benjamin, byen, Balzac“ in Kritik, II4 Henri Mitterand: „Formes et Fonctions de l'espace dans le Huenen et Paul Perron, (éd), Didier: Montréal, Québec, 1980

Franco Moretti: Atlas of the European Novel, Verso: London, New York, 1998

Christopher Prendergast: Paris and the Nineteenth Century, Blackwell Publishers: Oxford (UK) \& Cambridge (USA), 1992

Michel Raynaud: Figures de la nécessité - Espace et litterature: Développement de l'Urbanisme, 1978

Honoré de Balzac: La Comédie humaine, V, Gallimard, Pléiade (Pierre-Georges Castex udgaven), I977. (Histoire des Treize findes i en forkortet og dårlig dansk oversættelse
som De Tretten, Emil Wienes Forlag, Kbh. 1930)

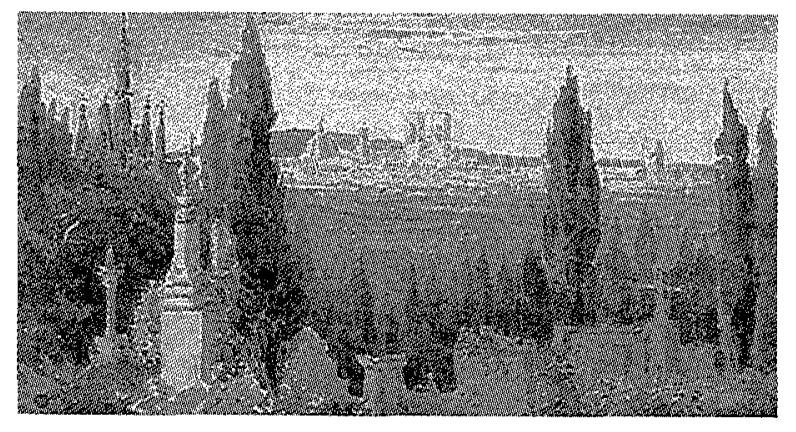

JUIA EMELY GoRdon (I8ro-I896) Père Lachaise. Akvarel 99 × $175 \mathrm{~mm}$

Noter

I. „Espace et langage“" og ,Figures“" fra samlingen Figures I samt "La litterature et l'espace“, som ogsa findes ove2. Cf. også Genette 1966, pp. 103-104.

3. Genette afholder sig dog ikke fra at kritisere ideen om et almindeligt, simpelt sprog uden troper og figurer - en ide der som bekendt ogsa senere er blevet kritiseret af poststrukturalismen. Selv den mest almindelige sprogbrug benytter sig af figurer og troper, og Genette påpeger at mest ophojede, sublime stil. Derfor foreslar $G$ med den tragte retorikken som et system af figurer $i$ stedet for at arbejde med en simpel dikotomi mellem figurativt og non-figurativt sprog (Genette, 1966, p. 208.) 4. I en note redegør Genette for, at han udelukkende be-
handler retorikkens elocutio (som har at gøre med udtryk- ket). Man kunne også her inddrage forholdet mellem retorik og rum udfra mnemoteknikken, som behandles Karen de León-Jones andetsteds i dette tidsskriftsnumm 5. ,Aujourd'hui la littérature - la pensée - ne se dit plu qu'en termes de distances, d'horizon, d'univers, de paysage, de lieu, de site, de chemins et de demeure : figures langes'space afin que l'espace, en lui, devenu langer. (Ge på et studium, der forsoger at konstruere et balzacsk Paris er Michel Raynauds meget inspirerende omend noget skitseagtige Figures de la nécessite Espace et Littérature : Paris et Balzac (Paris 1978). Raynaud kalder Balzacs Paris for et 'dokument-monument', hvis rum ikke er mindre beboeligt end et bykorts rum (p. 9). 7. „La figure est un écart par rapport à l'usage, lequel ecart est pourtant dans lusage : voila le paradoxe de la

terragus' bybeskrivelse $i$ en artikel, hvor han $i$ en polemik rettet mod Benjamin og den 1 urbane kulturstudier indflydelsesrige BenJanin-reception, diskuterer litteraturens behandling af det urbane bl.a. gennem genius loci figuren. Hos Balzac vendes genius loci figuren på vrangen, og Balzac vælger , forsoge sig frem med en flerhed af beskrivende tilnærmeser i en ombrydning af de fortallende genrers traderede former..." (Larsen, pp. 94-95). I Ferragus sker der iffolge hvor overblikket og de klassiske fremsillingsformer vendes på vrangen: „Stedsbeskrivelsen nedbryder byen som sted; skildringen af byen gennem dens personer nedbryder deres suverænitet, begge dele i distancerende dialog med traderede fremsillings- og erkendelsesformer" (Larsen, p. 98).

9. Balzac, V, 1977, p. 794 - Balzac vender iøvrigt tilbage til flanoren $i$ de indledende beskrivelse til den sidste ro man $\mathrm{i}$ Histoire des Treize, La Fille aux yeux d'or (Balzac, p. kring flanørmotivet og fortalleren som flanør.

to. Henri Mitterand kommer med en Aanor. for betydningen af denne væren på det forkerte sted i Ferragus. Balzacs Paris er en yderst opdelt by, hvor forskellige sociale klasser hører hjemme i forskellige bydele, og Mitterand udpeger forskellene og forbindelserne mellem de fire væsentlige kvarterer i Ferragus, hvor hovedpersonerne bor: Faubourg St. Germain (de Malincour - det gamle legitimistiske aristokrati), Chausee d'Antin (Jules Desmaret

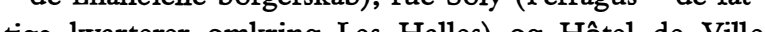
(prefekten - den royale administration). Mitterands las- ing viser, hvordan Balzac bruger det opdelte parisiske um til at portrættere et ustabilt, klasseopdelt samfund midt i mellem revelcioneme 1 1 830 og 1848 . Mitterand nár frem til at: „Le code proairetique, le code herméneuique et la 'topostructure' se presupposent réciproque(M) " (Mitternd, Det er faktisk Ferragus som hemmeligt tilretele de forhold, der gor Jules Desmarets rig efter at have giftet sig med Clémence (Mme Jules). På denne måde bliver Ferragus' beskidte og umoralske penge ved en simpel operation vasket hvide i det nye financielle borgerskab. De dunkle oprindelser til borgerskabets penge er i ovrigt et tilbageve Goriot. 2. En scene i Ferragus, hvor Jules udspionerer et afgoende mode mellem Mme Jules og Ferragus fra nabolejonskelig tydelighed denne dynamik. Situationen er for indviklet til at gøre rede for her, men mødet handler om at Ferragus fra da af vil være i stand til at kontrollere plottet og tildække sin identitet som galejslave. Ferragus ville således have kontrollen, men alt dette hører den spionerende Jules, hvilket placerer ham endnu hojere i kontrolhierarkiet. Imidlertid bliver Jules afsløret af et skrig (som er relateret til en anden gren af plottet), hvilket vækker trollierarki til at styrte sammen. David $\mathrm{F}$ Bell leverer fyldestgorende losing af denne pisiode of koverer en Hver gang en af karaktereme tror sig sikker og med fuld kontrol over en given situation, så kommer nogen til fuld bagved eller over ham og underminerer ham" (Bell, I993, p. I29).

13. Omkring det panoramiske som figur hos Balzac se evt. min artikel: „Panoramisk urbanisering - Paris som medie hos Balzac og i 1800-tallets realistiske medievirkelighed" i Passage, 22, 1996. For en lessning af Le pere Goriot se evt. med udgangspunkt $i$ La Peau de chagrin og Le père Goriots Aarhus: Litteraturhistorisk Forlag, I994

44. Cf. de Certeau pp. I59-I6s: „On n'habite que des lieux hantés - schema inverse de celui du Panopticon" (p. I62) („,Man beboer kun steder, hvor det spgger - hvilket er det omvendte skema af panoptikonnets"). Gennemskuelige steder er således ubeboelige og må praktiseres, forsynes med erindring, tidslighed, fortalling for at gøres beboelige.

5. Mærkværdigt nok kommer han overhovedet ikke oming Ferragus men holder sig til de mere kendte Le père Goriot og Mlusions perdues. 